\title{
FAKTOR ETIKA DALAM PENGELOLAAN SUMBERDAYA PERIKANAN DI INDONESIA ${ }^{1}$
}

\author{
Rilus A . Kinseng ${ }^{2}$ \\ ${ }^{1}$ Makalah ini telah dipresentasi pada World Ocean Conference (WOC), Manado, 11-15 Mei 2009. \\ ${ }^{2}$ Penulis adalah dosen di Departemen Komunikasi dan Pengembangan Masyarakat, \\ Fakultas Ekologi Manusia, Institut Pertanian Bogor, Indonesia.
}

\begin{abstract}
ABSTRAK
Etika menyangkut perilaku manusia yang dianggap baik atau buruk, pantas atau tidak pantas. Kini disadari bahwa etika tidak hanya menyangkut interaksi atau hubungan antar sesama manusia, tetapi juga sangat penting dalam pengelolaan sumberdaya alam. Tujuan tulisan ini adalah untuk menunjukkan pentingnya memperhatikan faktor etika dalam pengelolaan sumberdaya perikanan di Indonesia. Metode yang digunakan adalah studi literatur yang dikombinasikan dengan pengalaman lapang penulis. Kedua sumber ini dijadikan sebagai bahan refleksi pemikiran secara teoritis. Data tersebut digunakan untuk pengembangan ide atau pemikiran lebih lanjut pada tulisan ini. Keadilan sosial merupakan satu bentuk etika sosial yang sangat penting diperhatikan dalam pengelolaan sumberdaya perikanan, termasuk dalam penetapan zona penangkapan maupun perijinan alat tangkap. Dari segi etika lingkungan, etika lingkungan yang dominan di kalangan pengguna sumberdaya perikanan di Indonesia adalah antroposentrisme. Oleh sebab itu, pengelolaan sumberdaya perikanan seperti penetapan kawasan konservasi laut harus memperhatikan implikasi dari etika lingkungan ini. Tulisan ini mengusulkan perlunya mendekonstruksi etika antroposentrisme dan menggantikannya dengan etika "teosentris".
\end{abstract}

Kata Kunci: Etika, Lingkungan, Keadilan, Perikanan

\section{Abstract: Ethical Factor in the Fisheries Management in Indonesia. By: Rilus A. Kinseng}

Ethics is about human conduct that considered as good or bad, proper or not proper. However, it has been acknowledged that ethics is not only important in the relation among people (human being), but also in relation between humans and their environment. The objective of this paper is to show the important of ethics to be taken into account in managing fishery resources in Indonesia. The method used was literature study combine with the author's field experiences. These data and as information where used to develop ideas and thoughts in this paper. It was argued that social justice is one of the social ethics that is very important to be considered, for example in establishing fishing zones as well as in permitting type of fishing gear to be used. Regarding environmental ethics, it was argued that the most common and dominant ethics among fishery resources users in Indonesia is anthropocentrism. Therefore, fishery resource management should pay serious attention to its implication in managing fishery resources, such as in the case of establishment of marine protected areas. This paper contended that it is needed to deconstruct the anthropocentrism and replace it with "theocentrism".

Keywords: Ethics, Environment, Justice, Fishery 


\section{PENDAHULUAN}

Pada dasarnya etika menyangkut perilaku manusia yang dianggap baik atau buruk. Etika menentukan perilaku apa yang dipandang baik dan perilaku apa pula yang dipandang buruk dalam suatu komunitas atau masyarakat tertentu. Etika merupakan sistem nilai dan norma yang "mengontrol" perilaku manusia. Oleh sebab itu, etika biasanya lebih sering dibahas dan dikaji dalam ilmu-ilmu sosial dalam kaitannya dengan masalah interaksi sosial antara sesama manusia. Namun, dengan merebaknya krisis lingkungan atau krisis ekologi, masalah etika telah menjadi topik penting dalam diskursus pengelolaan lingkungan dewasa ini. Seperti dikatakan oleh Keraf (2006), krisis ekologi bukan hanya persoalan teknis semata, tetapi juga merupakan persoalan moralitas dan etika. Jauh sebelumnya, yakni pada tahun 1970, Lynn White, dalam tulisannya yang sangat terkenal yang berjudul The Historical Roots of Our Ecological Crisis telah menyatakan bahwa akar dari krisis ekologi yang dialami oleh dunia adalah nilai-nilai yang bersumber dari ajaran agama. Tidak heran jika Arne Naess mengatakan bahwa krisis lingkungan yang kita hadapi dewasa ini hanya dapat diatasi jika pandangan dan perilaku kita terhadap lingkungan diubah secara radikal (Keraf, 2006).

Faktor etika ini tentunya sangat penting juga dalam pengelolaan sumberdaya perikanan di Indonesia. Berbagai persoalan dalam pengelolaan sumberdaya perikanan seperti penetapan kawasan konservasi laut, penetapan sistem zonasi, jumlah tangkapan yang diperbolehkan, hak dan sistem pengelolaan "tradisional", modernisasi teknologi penangkapan (dulu dikenal dengan program motorisasi), dan sebagainya, bukanlah tanpa kaitan dengan etika. Oleh karena itu, maka faktor etika ini perlu diperhatikan dalam pengelolaan sumberdaya perikanan, termasuk di Indonesia tentunya.

Makalah singkat ini akan membahas beberapa isu seputar etika dalam kaitannya dengan pengelolaan sumberdaya perikanan di Indonesia. Diharapkan tulisan singkat ini dapat mendorong diskusi dan perdebatan yang lebih banyak dan mendalam lagi tentang hal-hal yang berkaitan dengan faktor etika dalam pengelolaan sumberdaya atau lingkungan, khususnya dalam pengelolaan sumberdaya perikanan di Indonesia. Selama ini, perhatian terhadap persoalan etika dalam pengelolaan sumberdaya perikanan di Indonesia rasanya masih kurang.

\section{METODOLOGI}

Metode yang digunakan dalam penulisan makalah ini adalah "studi pustaka", yang kemudian digabungkan dengan pengamatan dan pengalaman lapang penulis selama ini. Berdasarkan kedua sumber itu, selanjutnya penulis melakukan refleksi dan membangun pemikiran yang lebih bersifat teoritis.

\section{HASIL DAN PEMBAHASAN}

\section{Etika dalam Pengelolaan Sumberdaya Perikanan di Indonesia Etika Sosial: Keadilan Sosial}

Untuk membedakan dengan etika lingkungan, yang dimaksud dengan "etika sosial" disini adalah etika yang menyangkut hubungan atau interaksi antara manusia dengan sesama manusia. Dalam konteks pengelolaan sumberdaya perikanan, salah satu isu maha penting yang berkaitan dengan etika sosial ini adalah persoalan keadilan sosial (social justice). Sebagai contoh, kebijakan tentang jenis alat tangkap yang diijinkan mesti memperhatikan dampaknya terhadap keadilan sosial. Jika implementasi suatu alat tangkap itu menyebabkan marginalisasi segolongan kaum nelayan, khususnya nelayan kecil, maka menjadi tidak etis untuk melanjutkan program semacam itu, tanpa memberikan solusi alternatif yang adil bagi mereka. Prinsip yang sama juga berlaku untuk berbagai kebijakan lainnya, seperti 
pembangunan kompleks perumahan atau bahkan industri perikanan sendiri di wilayah komunitas nelayan. Jika kebijakan semacam itu menyebabkan marginalisasi dan pemiskinan kaum nelayan, maka itu bukanlah satu kebijakan yang baik.

Persoalan keadilan sosial ini juga sangat penting diperhatikan dalam penentuan zona tangkap atau sistem zonasi. Dalam hal zonasi ini ada dua isu khusus yang ingin dibahas. Pertama adalah hak pemanfaatan dan/atau"kepemilikan" secara tradisional atau oleh masyarakat lokal. Ada banyak wilayah tangkap (fishing ground) di Indonesia yang dianggap sebagai "tempat khusus" oleh masyarakat lokal yang berada di dekat lokasi wilayah tangkap tersebut. Meskipun mereka tidak mengklaim kepemilikan atas wilayah tersebut. Menurut mereka laut adalah milik bersama dan semua orang pada dasarnya bebas untuk melakukan penangkapan di laut, tetapi mereka merasa memiliki hak istimewa atau khusus atas wilayah tersebut karena mereka telah melakukan kegiatan penangkapan secara turun-temurun di tempat tersebut. Adanya hak istimewa ini antara lain diwujudkan dalam bentuk penolakan mereka terhadap nelayan luar yang beroperasi di wilayah tangkap tersebut jika menggunakan alat tangkap yang lebih "superior" dari alat tangkap yang mereka pakai. Biasanya mereka mengatakan bahwa nelayan luar boleh saja menangkap di wilayah mereka, asalkan menggunakan alat tangkap yang sama. Dengan kata lain, mereka merasa mempunyai hak dan kewenangan untuk menentukan "aturan main" yang berlaku di wilayah tangkap tersebut.

Wilayah tangkap penduduk lokal semacam itu bisa saja cukup jauh letaknya dari pantai. Sebagai contoh, di Balikpapan Kalimantan Timur, misalnya, wilayah tangkap "tradisional" nelayan lokal di sana letaknya mencapai jarak 40 mil dari pantai. Ini mempunyai implikasi penting dalam penetapan zonasi. Sebagai contoh, dalam Keputusan Menteri Pertanian (KEPMENTAN)
No. 392/1999 jalur penangkapan ikan dibagi menjadi tiga, yakni: jalur I (0-6 mil), jalur II (6-12 mil), dan jalur III (12-200 mil). Surat keputusan itu juga menetapkan bahwa kapal perikanan berbendera Indonesia yang berbobot hingga 200 GT diperbolehkan beroperasi di jalur III. Artinya, kapal perikanan skala besar boleh masuk beroperasi di wilayah tangkap nelayan tradisional di wilayah Balikpapan tersebut. Ketika kapal besar masuk dan beroperasi di wilayah tangkap nelayan lokal yang tingkat teknologinya jauh dibawah, maka yang terjadi adalah sebuah persaingan yang tidak seimbang. Dalam hal ini nelayan lokal atau sering mereka sebut sebagai "nelayan tradisional", akan kalah bersaing. Hal ini seringkali memicu konflik sosial antara nelayan lokal yang "kecil" dan nelayan luar yang "besar", seperti yang terjadi antara nelayan "tradisional" di Balikpapan dengan nelayan purse seine dari Juwana, Jawa Tengah, pada awal tahun 2006. Dalam kasus ini, satu kapal nelayan purse seine dari Juwana tersebut dibakar oleh "nelayan taradisional" di Balikpapan (Kinseng, 2007).

Di beberapa daerah di Indonesia bagian Timur, klaim atas wilayah tangkap oleh masyarakat lokal lebih kuat lagi. Dalam hal ini klaim atas wilayah tangkap bahkan juga pulaupulau kecil, tidak hanya sebatas "hak istimewa" untuk beroperasi dan menentukan "aturan main" di wilayah tersebut, tetapi kepemilikan (ownership) atas wilayah tersebut. Contoh yang paling populer adalah sistem sasi di wilayah Maluku, yang sudah berlangsung berabad-abad (Indrawasih, 2007). Dalam sistem sasi ini, suatu wilayah penangkapan bahkan pulau-pulau kecil di sekitar desa atau dusun, dimiliki oleh desa atau dusun tersebut. Wilayah yang dimiliki oleh desa atau dusun ini disebut dengan nama "petuanan". Masyarakat di desa atau dusun pemilik petuanan tersebut mempunyai kewenangan untuk mengatur pemanfaatan sumberdaya dalam wilayah petuanan itu, seperti buka dan tutup sasi ${ }^{3}$, juga jenis alat tangkap yang boleh digunakan, ukuran ikan

\footnotetext{
${ }^{3}$ Buka sasi berarti boleh dilakukan penangkapan atau pengambilan ikan dsb, sedangkan tutup sasi berarti tidak boleh dilakukan penangkapan atau pengambilan ikan dsb.
} 
yang boleh ditangkap, dan sebagainya. Di Maluku sebenarnya ada dua jenis sasi, yakni sasi negri yang kewenangannya berada di tangan pemerintah desa (negri), dan sasi gereja yang kewenangannya ada ditangan pejabat gereja.

Di beberapa daerah lainnya di Indonesia juga ada sistem pengelolaan sumberdaya yang serupa, misalnya awig-awig di Lombok dan panglima laut di Aceh. Masyarakat Papua juga memiliki sistem pengelolaan sumberdaya yang mirip. Dalam konteks keadilan sosial (juga keadilan lingkungan atau environmental justice) hak-hak masyarakat lokal baik hak pemanfaatan maupun "hak milik" tradisional semacam itu sangat perlu untuk dihormati, diakui, didukung, serta dilindungi. Ketika pemerintah menetapkan zona penangkapan, misalnya, maka eksistensi sistem pengelolaan oleh masyarakat lokal seperti ini penting diperhatikan dan dihormati.

Kedua, "jarak dominasi". Jarak dominasi adalah jarak teritorial di laut dimana dominasi dari nelayan yang menggunakan kapal ikan yang lebih besar masih dirasakan oleh para nelayan yang menggunakan kapal ikan yang lebih kecil atau dengan kata lain jarak di laut dimana dominasi nelayan besar terhadap nelayan kecil masih berlaku. Sebagai contoh, menurut para "nelayan tradisional" di Balikpapan, Kalimantan Timur, dominasi nelayan besar yang menggunakan alat tangkap purse seine di wilayah perairan sekitar Balikpapan mencapai hingga jarak sekitar lima mil. Pada jarak tersebut, ikan-ikan "tersedot" oleh nelayan purse seine sehingga nelayan lokal sangat sulit untuk mendapatkan ikan. Jarak yang cukup jauh ini dipengaruhi oleh teknologi penangkapan yang digunakan oleh nelayan purse seine tersebut. Dalam hal ini, penggunaan lampu yang sangat kuat baik di atas permukaan air maupun di dalam air laut merupakan faktor yang sangat penting. Penggunaan lampu inilah yang "menarik" ikan-ikan dan sebagainya dari wilayah perairan dengan jarak yang cukup jauh itu. Oleh sebab itu, penggunaan lampu ini menjadi suatu isu penting dalam konflik antara nelayan lokal Balikpapan dengan nelayan purse seine dari Jawa di wilayah perairan Selat Makassar pada tahun 2006.

Dari perspektif keadilan sosial, adalah tidak adil membiarkan nelayan kecil bertarung dengan nelayan besar dalam upaya memperoleh ikan di suatu wilayah penangkapan. Ini sama dengan "hukum rimba" atau "survival of the fittest": yang kuat yang menang. Itulah yang terjadi manakala kapal penangkapan berskala besar dibiarkan beroperasi di wilayah tangkap yang dekat dengan nelayan kecil, atau nelayan kecil berada dalam jarak dominasi nelayan besar. Oleh sebab itu, maka dalam penentuan zona penangkapan, persoalan "jarak dominasi" dari nelayan besar ini sangat penting untuk diperhatikan.

\section{Etika Lingkungan yang Dominan}

Sebelum mendiskusikan etika lingkungan yang dominan di kalangan para "pengguna" dan pengelola sumberdaya perikanan di Indonesia, terlebih dahulu ingin dikemukakan beberapa etika lingkungan itu sendiri secara ringkas. Secara singkat, etika lingkungan adalah norma-norma dan sistem nilai yang menyangkut alam atau lingkungan, yang mempengaruhi perilaku manusia terhadap alam atau lingkungan tersebut. Deane-Drummond (1996), "The specific task of environmental ethics is to develop principles regarding human action in the non-human world". Namun, menurut Keraf (2006), etika lingkungan belakangan ini dipahami secara lebih luas, tidak hanya berbicara mengenai perilaku manusia terhadap alam. "Etika lingkungan hidup juga berbicara mengenai relasi di antara semua kehidupan alam semesta, yaitu antara manusia dengan manusia yang mempunyai dampak pada alam dan antara manusia dengan makhluk hidup lain atau dengan alam secara keseluruhan" (Keraf, 2006).

Sekedar menyegarkan ingatan kita, ada beberapa etika lingkungan yang telah 
diketahui dan diperbincangkan secara luas. Pertama, antroposentrisme. Pada dasarnya antroposentrisme memandang bahwa manusia merupakan "pusat" dunia; manusialah yang mempunyai nilai intrinsik. Manusia memiliki posisi yang lebih tinggi dari mahluk dan benda-benda yang lain. Mahluk dan benda-benda yang lain hanya mempunyai nilai jika ia memiliki kontribusi atau berguna bagi kepentingan manusia. Mahluk dan benda-benda yang lain ada untuk "melayani" kepentingan manusia. Seperti kata White , dalam pandangan antroposentrisme, "...nature has no reason for existence save to serve man" (White, 1970). Etika ini dikenal pula sebagai "etika lingkungan yang dangkal" atau "shallow environment ethics" (Keraf, 2006).

Kedua, biosentrisme. Dalam pandangan ini, semua mahluk hidup memiliki nilai pada dirinya sendiri (mempunyai nilai intrinsik), terlepas apakah ia berguna atau tidak bagi manusia. Jadi, pusat perhatian adalah pada hidup atau kehidupan itu sendiri. Seperti kata Deane-Drummond (1996), "In the biocentrism view,... the value given to humans is extended to include all living creatures". Etika Bumi atau land ethics yang dipelopori oleh Aldo Leopold, misalnya, merupakan salah satu etika lingkungan yang berada dalam kelompok biosentrisme ini (Keraf, 2006). Ketiga, ekosentrisme. Jika biosentris memperluas cakupan etika kepada seluruh mahluk hidup, maka ekosentrisme memperluas etika lebih jauh lagi yakni mencakup komunitas ekologi secara keseluruhan, baik mahluk hidup maupun benda mati (living and non-living). Jadi, tanggung jawab moral itu berlaku bukan hanya kepada mahluk hidup, melainkan kepada benda-benda yang tak hidup (seperti tanah, air, udara, batu, dsb).

Merujuk pada tiga kelompok etika lingkungan yang disebutkan di atas, maka menarik untuk dikaji, etika mana yang paling umum atau dominan berlaku di kalangan para pengelola dan pengguna sumberdaya perikanan di Indonesia, khususnya kaum nelayan? Saya berpendapat bahwa etika lingkungan yang paling umum atau dominan di kalangan para pengelola dan pengguna sumberdaya perikanan di Indonesia, termasuk para nelayan, adalah antroposentrisme. Sumberdaya perikanan dinilai terutama atas dasar manfaatnya bagi kehidupan manusia, baik ekonomi maupun non-ekonomi. Pemeliharaan atau konservasi lingkungan pun dilakukan bukan karena memandang bahwa alam itu mempunyai nilai pada dirinya sendiri atau mempunyai hak untuk eksis, tetapi lebih merupakan upaya untuk menjaga kepentingan manusia secara berkelanjutan.

Hal ini sangat penting untuk dipahami oleh berbagai pihak yang terlibat dalam pengelolaan sumberdaya perikanan, seperti pemerintah dan LSM, misalnya. Sebagai contoh, dalam membangun program konservasi seperti Taman Nasional Laut, maka dampaknya terhadap mata pencaharian penduduk di sekitar kawasan tersebut sangat perlu diperhatikan. Upaya menetapkan kawasan konservasi kadangkala ditentang keras oleh masyarakat lokal karena mengancam matapencaharian mereka. Bahkan secara sinis masyarakat lokal mengatakan: mana yang lebih penting, manusia atau terumbu karang. Sudah tentu, bagi mereka, manusia (mereka) lebih penting daripada terumbu karang (antroposentrisme). Inilah yang seringkali memicu konflik antara masyarakat lokal dengan pihak pengelola kawasan konservasi laut (Gustav dan Farid, 2004).

\section{Antroposentrisme dan Keberlanjutan Sumberdaya Alam}

Dapatkah kita mengelola sumberdaya alam (perikanan) secara berkelanjutan dalam kerangka etika lingkungan yang bersifat antroposentrisme? Atau, apakah hanya etika lingkungan yang biosentris dan ekosentris saja yang memungkinkan untuk mencapai pengelolaan sumberdaya alam yang berkelanjutan? 
Menurut Kinseng (2003), pengalaman atau data menunjukkan bahwa pengelolaan sumberdaya alam yang berkelanjutan bisa saja dicapai sekali pun dalam kerangka etika lingkungan yang bersifat antroposentris. Saya ingin mengemukakan dua kasus di bidang kehutanan yang baru-baru ini kami pelajari, sebagai contoh konkrit. Pertama, pengelolaan hutan oleh masyarakat Dayak Hibun di Kecamatan Tayan Hulu, Kalimantan Barat. Dalam kasus ini, masyarakat Dayak Hibun di kecamatan tersebut menetapkan hutan di wilayah bukit Semaung-Sepapan sebagai hutan lindung/hutan adat. Salah satu alasan penting penetapan tersebut adalah untuk menjaga dan memelihara roh-roh yang dianggap berperan untuk memelihara dan melindungi masyarakat Dayak Hibun di sekitar lokasi tersebut, termasuk roh nenek moyang mereka. Hal ini perlu dilakukan agar roh-roh tersebut tidak marah yang pada gilirannya akan mendatangkan malapetaka bagi masyarakat Dayak Hibun tersebut, misalnya gagal panen, sakit, hingga meninggal dunia. Selain itu, penetapan kawasan tersebut sebagai hutan lindung juga dilakukan untuk menjamin ketersediaan kayu bagi kebutuhan hidup mereka dan juga anak cucu mereka nantinya. Tujuan lainnya adalah agar mereka masih mempunyai tempat untuk berburu, serta untuk melindungi sumber air yang mereka perlukan dalam kehidupan sehari-hari. Dengan demikian, maka alasan masyarakat Dayak Hibun untuk melakukan konservasi hutan Semaung-Sepapan ini adalah untuk kepentingan mereka. Jadi, ini merupakan etika lingkungan yang antroposentris.

Contoh yang kedua adalah pengelolaan sumberdaya perikanan dan kehutanan yang dilakukan oleh komunitas Melayu di Desa Semangit, Kalimantan Barat. Dalam kasus ini, komunitas Melayu tersebut melakukan pengelolaan sumberdaya perikanan dan kehutanan secara baik untuk menjamin keberlanjutan pendapatan mereka baik dari ikan maupun dari madu. Di bidang perikanan, mereka membuat aturan berupa larangan menggunakan racun maupun jala yang lubangnya berukuran sangat kecil. Di bidang kehutanan, mereka melarang membakar hutan agar lebah tidak "lari" dari wilayah itu serta untuk menjaga kualitas madu yang dihasilkan. Jadi, semua aturan "konservasi" itu mereka tetapkan untuk menjamin keberlanjutan mata pencaharian hidup mereka. Dengan kata lain, ini adalah etika lingkungan yang antroposentris.

Dalam etika lingkungan yang bersifat antroposentris, ada dua unsur yang dapat mendorong manusia untuk melakukan konservasi. Yang pertama adalah keuntungan. Apakah kegiatan konservasi itu memberikan keuntungan bagi masyarakat? Keuntungan ini bisa berupa ekonomi (uang), keberlanjutan hidup sehari-hari (misalnya bahan-bahan makanan dll), sosial (misalnya penghargaan), ataupun spiritual. Jika masyarakat memahami bahwa kegiatan konservasi itu memberikan keuntungan, maka mereka akan terdorong untuk melakukan konservasi. Atau jika mereka memahami bahwa mata pencaharian atau kehidupan mereka tergantung pada pemeliharaan lingkungan hidup, mereka akan terdorong untuk memelihara lingkungan hidup mereka dengan baik. Seperti kata Friedmann, "It is an empirically verifiable phenomenon that people wish to protect the environment on which they depend for their life and livelihood" (Friedmann, 1998:81).

Unsur yang kedua adalah orientasi jangka panjang. Jika masyarakat mempunyai orientasi jangka panjang, misalnya memperhatikan kepentingan generasi yang akan datang atau anak-cucu mereka secara sungguh-sunguh, maka mereka akan terdorong untuk memelihara lingkungan dengan lebih baik. Ini dijumpai pada kasus komunitas Dayak Hibun di Kalimantan Barat yang disebutkan tadi. Menariknya, sekalipun hanya ada satu atau dua orang tokoh saja yang memiliki orientasi jangka panjang, tokoh tersebut dapat memainkan peranan yang sangat signifikan bagi komunitasnya secara 
keseluruhan dalam upaya-upaya mewujudkan pengelolaan sumberdaya alam yang berkesinambungan. Hal ini dijumpai pada kajian kami di kalangan Dayak Hibun di Semaung-Sepapan seperti diuraikan sebelumnya, maupun pada komunitas rumah panjang Dayak Iban di Sungai Utik, Kalimantan Barat.

\section{"Back to Religion"}

Dalam bukunya yang berjudul: A Handbook in Theology and Ecology, Celia Deane-Drummond (1996) mengemukakan etika lingkungan yang lain, yakni etika yang berpusat pada Tuhan (God-centric) atau teosentris. Menurut dia, etika ini melampaui etika antroposentrisme maupun biosentrisme. Dia katakan bahwa etika teosentris ini "beyond either an anthropocentric or biocentric approach. It recognizes the value of all creation, but also sees the place of human responsibility".

Etika teosentris ini sangat menarik dan mempunyai peluang yang sangat besar dan baik untuk berkembang di Indonesia, dibandingkan dengan etika biosentris maupun ekosentris, mengingat agama masih mempunyai peranan yang sangat penting dalam kehidupan bangsa Indonesia. Mendorong tumbuh kembangnya etika lingkungan yang berbasis pada agama (teosentris) ini berarti "kembali pada agama", yang selama ini sudah lama "ditinggalkan" terutama di dunia Barat. Sebenarnya, Lynn White juga berpendapat bahwa karena akar dari krisis ekologi itu bersumber pada nilai agama, maka penyelesaiannyapun mestilah bersumber pada agama pula. Dia katakan: "Since the roots of our trouble are so largely religious, the remedy must also be essentially religious, whether we call it that or not" (White, 1970).

Semua agama mengandung ajaran yang mendorong para pemeluknya untuk menjaga dan memelihara lingkungan dengan sebaik-baiknya ("green teaching"). Sebagai contoh, agama mengajarkan bahwa alam semesta beserta manusia itu merupakan ciptaan dan milik Tuhan. Manusia diberi mandat secara terbatas oleh Tuhan untuk memelihara ciptaan Tuhan tersebut dengan sebaik-baiknya. Manusia bertanggung jawab kepada Tuhan dalam pengelolaan alam dan lingkungan. Alam semesta harus dikelola untuk kemuliaan Tuhan, sang Penciptanya, bukan untuk memuaskan keinginan dan keserakahan manusia. Bahkan manusia-pun diciptakan untuk kemuliaan Tuhan. Jadi, pusatnya adalah Tuhan (God-centric).

Dalam kaitan ini, jika Lynn White berpendapat bahwa Agama Kristen merupakan akar krisis ekologi, hemat saya tidak demikian ${ }^{4}$. Yang menjadi akar krisis ekologi bukan ajaran Kristen itu sendiri, tetapi sebaliknya justru karena ajaran Kristen itu tidak dilaksanakan secara murni dan konsekuen. Ada banyak ajaran Kriten yang sangat mendorong perilaku konservasi atau pengelolaan alam yang baik, misalnya ajaran tentang penciptaan seperti yang telah disinggung di atas, maupun ajaran tentang sikap terhadap materi dan kebahagiaan (Deane-Drummond, 1996).

\section{KESIMPULAN DAN IMPLIKASI KEBIJAKAN}

\section{Kesimpulan}

- Faktor etika memegang peranan yang penting dalam pengelolaan sumberdaya perikanan di Indonesia. Salah satu aspek dari faktor etika ini adalah keadilan sosial.

- Etika lingkungan yang paling umum dan dominan di kalangan para pengguna dan pengelola sumberdaya perikanan di Indonesia, termasuk para nelayan, sejauh ini adalah etika antroposentisme. Ini bukan berarti bahwa konservasi tidak dapat dilaksanakan. Dalam konteks antroposentrisme, konservasi masih bisa dilaksanakan, namun dengan pendekatan yang tepat sesuai dengan sifat antroposentrisme tersebut.

\footnotetext{
${ }^{4}$ Kritik terhadap pendapat Lynn White ini juga disampaikan oleh Michael Mayerfeld Bell dalam bukunya: An Invitation to Environmental Sociology (2004).
} 
- Etika lingkungan yang berbasis pada agama, yakni teosentris (berpusat pada Tuhan) nampaknya mempunyai kemungkinan dan peluang yang baik untuk ditumbuhkembangkan di Indonesia. Hal ini sesuai dengan karakter bangsa Indonesia yang bersifat religius.

\section{Implikasi Kebijakan}

- Faktor etika, berupa keadilan sosial, perlu diperhatikan dalam mengelola sumberdaya perikanan di Indonesia, seperti modernisasi dan perijinan alat tangkap, penetapan zona tangkap, penetapan kawasan perlindungan (konservasi) laut, penetapan tingkat eksploitasi perikanan, penanganan hakhak tradisional, dan sebagainya. Demikian juga dengan kegiatan dan pembangunan yang berkaitan dengan kehidupan para nelayan, seperti kegiatan pertambangan, pembangunan kawasan perumahan di pingir pantai, dan sebagainya. Jika suatu program itu menyebabkan marginalisasi dan pemiskinan sekelompok nelayan, sebaiknya program tersebut tidak dilaksanakan.

- Mengingat bahwa etika lingkungan yang dominan adalah antroposentris, maka ada dua unsur penting yang dapat mendorong tindakan konservasi dan pemanfaatan yang berkelanjutan. Pertama adalah keuntungan (jangka pendek), baik keuntungan ekonomi, sosial, maupun spiritual. Jika kegiatan konservasi itu memberi keuntungan, maka orang akan bersedia melakukannya. Sebaliknya, jika orang merasa rugi dengan melakukan konservasi, orang akan sulit diajak untuk melakukannya. Oleh sebab itu, pemahaman dan kesadaran akan keuntungan yang diperoleh dari suatu tindakan konservasi atau pemanfaatan yang ramah lingkungan menjadi penting ditumbuhkan pada masyarakat pengguna sumberdaya perikanan. Kedua adalah orientasi jangka panjang. Jika masyarakat mempunyai orientasi jangka panjang, misalnya demi kepentingan anak-cucu, maka mereka akan mudah melakukan konservasi dan pemanfaatan yang berkelanjutan. Oleh karena itu, orientasi jangka panjang ini juga sangat penting ditumbuhkan di kalangan pengguna sumberdaya perikanan.

- Upaya untuk mendekonstruksi etika lingkungan yang antroposentris dan menggantikannya dengan etika yang lain juga perlu dilakukan. Untuk itu, perlu dikembangkan etika alternatif, yakni teosentris. Etika ini menempatkan Tuhan sebagai pusat dunia. Manusia memang diberi mandat untuk mengelola alam, tetapi tidak untuk merusak dan menggunakan seenaknya untuk kepentingan dan kesenangan manusia itu sendiri. Semuanya mesti dilakukan untuk kemuliaan Tuhan, sang Pemiliknya. Manusia harus mempertanggung jawabkan segala tindakannya kepada Tuhan. Ini sangat sejalan dengan ajaran agama-agama yang dianut oleh masyarakat Indonesia yang memiliki Pancasila sebagai falsafah negara tentunya.

\section{Daftar Pustaka}

Drummond. 1996. A Hanbook in Theology and Ecology. SCM Press Ltd. London.

Friedmann. 1998. Empowerment. The Politics of Alternative Development. Blackwell, Cambridge MA \& Oxford UK.

Gustav dan Farid. 2004. "Di Bawah Kebijakan Konservasi Fasis" dalam Nur Hafsah (Penyunting), 2004. Potret Pelanggaran Hak Asasi Petani dan Nelayan. Sekretariat Bina Desa, Jakarta.

Indrawasih, R. 2007. Konflik-konflik Kenelayanan: Distribusi, Pola, akar Masalah dan Resolusinya. LIPI. Jakarta.

Keraf, S. 2006. Etika Lingkungan. KOMPAS. Penerbit Buku Kompas, Jakarta. 
Kinseng, R. A. 2003. "Antroposentrisme dan SDA". Koran Republika, 20 Agustus, 2003.

2007. Kelas dan Kelas Konflik pada Kaum Nelayan di Indonesia (Studi Kasus di Balikpapan, Kalimantan Timur). Disertasi. Departemen Sosiologi, FISIP. Ul. Jakarta.
White, Jr. 1970. The Historical Roots of Our Ecological Crisis in Garrett de Bell (ed), 1970. The Environmental Handbook. Prepared for the First National Environmental Teach-In. Ballantine Books Inc., New York. 